\title{
Precursor Processing of Human Defensin-5 Is Essential to the Multiple Functions in vitro and in vivo
}

\author{
Chisato Ishikawa ${ }^{a}$ Hiroki Tanabe ${ }^{a}$ Atsuo Maemoto ${ }^{a}$ Takahiro Ito $^{a}$ Jiro Wataria \\ Toru Kono $^{\mathrm{b}}$ Mikihiro Fujiya $^{\mathrm{a}}$ Toshifumi Ashida $^{\mathrm{a}}$ Tokiyoshi Ayabe ${ }^{\mathrm{c}}$ \\ Yutaka Kohgo a \\ ${ }^{a}$ Division of Gastroenterology and Hematology/Oncology, Department of Internal Medicine and \\ ${ }^{b}$ Division of Surgical Gastroenterology, Department of Surgery, Asahikawa Medical College, Asahikawa, and \\ 'Innate Immunity Laboratory, Department of Cellular Life Science, Faculty of Advanced Life Science, \\ Hokkaido University, Sapporo, Japan
}

\section{Key Words}

Antimicrobial peptides - Defensins $\cdot$ Host defense $\cdot$ Protein function

\section{Abstract \\ Human defensin-5 (HD-5) is one of the major antimicrobial peptides secreted by Paneth cells in the human small intes- tine. HD-5 is produced and stored as a propeptide in Paneth cell granules, secreted in response to stimulation by cholin- ergic reagents or bacterial antigens. The activation process by trypsin occurs in the intestinal lumen to produce mature HD-5. This study evaluated the difference between proHD-5 and mature HD-5 in bactericidal activity and induction of chemokine secretion in vitro. Mature HD-5 showed bacteri- cidal activities against all bacterial strains. Though, proHD-5 without enzymatic cleavage possessed less antimicrobial ability against Salmonella typhimurium and Escherichia coli but not against Staphylococcus aureus. Mature HD-5 also in- duced intestinal epithelial cells to increase the protein and mRNA levels of interleukin-8. Furthermore, the peptides were applied to dextran sulfate sodium-induced mouse coli- tis. The expression of endogenous mouse defensins was not}

\section{KARGER}

Fax +4161306 1234

E-Mail karger@karger.ch

www.karger.com
(C) 2009 S. Karger AG, Basel

$1662-811 X / 10 / 0021-0066 \$ 26.00 / 0$

Accessible online at:

www.karger.com/jin changed in the small intestine, and the additional injection of exogenous HD- 5 improved mortality $(p<0.05)$. This study demonstrated the multifunctional roles of the activation process in human defensin and the possibility of using antimicrobial peptides for the treatment of inflammatory bowel diseases in future applications.

Copyright $\odot 2009$ S. Karger AG, Base

\section{Introduction}

Innate immunity is a widely conserved mechanism to protect hosts from environmental pathogens. Intestinal epithelial cells are exposed to numerous microbes and food-borne antigens because the intestine has a huge surface area for nutrient absorption. The first barrier against luminal microbes in the intestine is composed of surface epithelial cells and products secreted by some epithelial cells $[1,2]$. The intestinal epithelium is composed of cells from 4 cell lineages: absorptive cells, goblet cells, enteroendocrine cells and Paneth cells. Paneth cells are specialized cells located at the bottom of small intestinal crypts $[3,4]$. These well-differentiated cells, sensing bacteria and 
bacterial antigens, release granules including antimicrobial peptide complexes $[2,5]$. Antimicrobial peptides are functional molecules secreted into the lumen to prevent bacteria from invasion. The mouse Paneth cell granules contain several defensin peptides, lysozyme, secretory phospholipase $\mathrm{A}_{2}$, cryptdin-related sequences, angiogenin-4 and RegIII $\gamma$ [6-10]. The expressions of defensin and cryptdin-related sequences are abundant in arrays of antimicrobial peptides of mouse small intestine [10]. The antimicrobial activity secreted by mouse isolated intestinal crypts is largely due to enteric defensins $[1,5]$. Human defensin-5 (HD-5) and HD-6 were identified in humans $[6,11]$. Human small intestinal crypt cells express high levels of the innate antimicrobials HD-5, HD-6, lysozyme, phospholipase $\mathrm{A}_{2}$ and Reg3A (human ortholog of RegIII $\gamma$ ) [12].

The function of HD-5 in vivo is clearly demonstrated with gene-targeting mouse models. HD-5 transgenic mice are resistant to the oral challenge of Salmonella [13]. The transgenic mice express HD-5 specifically in Paneth cells, and the HD-5 peptide is stored as a propeptide (proHD-5) in the intestinal tissue, while the mature form is detected in the luminal contents. The details of the activation process in humans were determined by Bevins and colleagues [14]. The activation of the HD-5 peptide proceeds on the luminal surface after the Paneth cell granules are secreted into the intestinal lumen. Trypsin stored in Paneth cell granules is the processing enzyme which cleaves mature HD-5 from the proform. Interestingly, the proHD-5 which is synthesized in insect cells shows antibacterial activity against Listeria monocytogenes but not Salmonella typhimurium. A very recent report shows no activity of chemically synthesized proHD5 against Escherichia coli or Staphylococcus aureus [15]. The discrepancy between these antimicrobial activities is unclear.

Another function of defensins is as a bridge between innate and acquired immunity. Defensin induces acquired immunity through the production of cytokines from epithelial cells $[15,16]$. Interleukin-8 (IL-8) is a cytokine which is produced from epithelial cells occasionally in response to inflammation. Bacterial infection is one of the major mediators of inflammation in epithelial cells covering the surface of the intestinal mucosa. Two defensins, mouse cryptdin-3 and HD-5, induce IL- 8 secretion, forming a pore on the membrane of colonic cell lines [16, 17]. Surprisingly, cryptdin- 4 does not stimulate pore formation or induce cytokines [18]. The mechanisms of cytokine induction and the functional roles have not yet been characterized.

Processing of HD-5 Is Essential to

Functions
Recent findings regarding Paneth cell defensins include a report in which the loss of endogenous HD-5 is observed in the small intestinal involvement of Crohn's disease, while the other Paneth cell products remain unchanged $[19,20]$. One of the disease susceptibility genomes is NOD2, and its variants are observed in approximately $30 \%$ of all patients with ileal Crohn's disease. The NOD2 protein is a cytoplasmic receptor which recognizes bacterial antigens and is therefore an important molecule in intestinal innate immunity [21]. NOD2-deficient mice are susceptible to bacterial infection via oral route and lose the expression of mouse defensins. Another molecule regulating defensin expression is TCF4, a Wnt signaling pathway transcription factor, which binds to the HD-5 and HD- 6 promoters [22]. Reduced levels of TCF4 were found in patients with ileal Crohn's disease and therefore, the Paneth cell TCF4 is hypothesized to reduce defensin levels, thereby inducing a progression to ileal Crohn's disease [22,23]. Consequently, the supplement of intestinal defensins is considered to be one of the candidate molecular targets in the therapy of inflammatory bowel disease.

This study involved an antibacterial assay of defensins against 4 bacterial strains and cytokine release from epithelial cell lines. Furthermore, the therapeutic ability against dextran sulfate sodium (DSS) colitis was investigated. The role of enzymatic cleavage in bacterial protection and intestinal immunity was determined.

\section{Materials and Methods}

\section{Peptides}

Recombinant proHD-5 was produced in an E. coli expression system using a previously reported method [24]. The HD-5 was synthesized at the Peptide Institute, Inc. (Osaka, Japan). Its purity was checked by reversed-phase high-performance liquid chromatography (RP-HPLC; AKTAexplorer 10S; Amersham Biosciences, Piscataway, N.J., USA) and acid urea polyacrylamide gel electrophoresis (AU-PAGE), and the molecular masses were confirmed by the matrix-assisted laser desorption/ionization timeof-flight mass spectrometry. The concentrations were adjusted by $\mathrm{UV}$ absorption at $280 \mathrm{~nm}$ based on the extinction coefficients of the peptides $\left(3,355 \mathrm{M}^{-1} \mathrm{~cm}^{-1}\right.$ for HD-5 and proHD-5). The defensin peptides in all experiments were measured and utilized on a microgram basis. Therefore, it is important to note that the molarity of HD-5 was approximately twice that of proHD-5.

\section{Antimicrobial Activities}

The antibacterial activities were measured against $S$. typhimurium phoP-null strain, E. coli (DH5 $\alpha$ and ATCC 25922) and $S$. aureus (ATCC 25923). The bactericidal assay of the peptides in liquid media has been previously reported $[25,26]$. Briefly, $10^{6}$ colony-forming units (CFU) of log-phase bacteria are washed and

J Innate Immun 2010;2:66-76 
resuspended in $10 \mathrm{~mm}$ PIPES (pH 7.4) supplemented with $1 \%(\mathrm{v} / \mathrm{v})$ of trypticase soy broth, incubated with peptides at $37^{\circ} \mathrm{C}$ for $1 \mathrm{~h}$. An artificial medium was used for the assay because a culture medium such as trypticase soy broth inhibits the bactericidal activity of HD-5 [25].

\section{Cell Culture and Measurement of Cytokine Release}

Colonic cancer cell lines were used as the model of epithelial cells. SW480 (ATCC CCL-228) and HT29 (ATCC HTB-38) were obtained from the American Type Culture Collection and maintained in DMEM supplemented by $10 \%$ fetal calf serum (Biosource; Invitrogen, Carlsbad, Calif., USA), $50 \mathrm{U} / \mathrm{ml}$ penicillin, 50 $\mu \mathrm{g} / \mathrm{ml}$ streptomycin, $4 \mathrm{mM}$ L-glutamine and $1 \times$ nonessential amino acid in $5 \% \mathrm{CO}_{2}$ at $37^{\circ} \mathrm{C}$. All reagents without description were obtained from Sigma-Aldrich Japan (Tokyo, Japan). The cells were incubated in 6-well culture clusters, washed twice with the media without serum and then incubated with individual peptides for appropriate terms. The supernatant was collected after $24 \mathrm{~h}$ incubation and the released cytokines were examined using a human cytokine antibody array (RayBiotech, Inc., Norcross, Ga., USA). The antibody array membranes were incubated in the conditioned media and the procedure was followed according to the manufacturer's guidelines. Chemiluminescence was detected with LAS-3000 (Fujifilm, Tokyo, Japan). ELISA kits for IL-8 (Endogen, Rockford, Ill., USA), growth-regulated oncogene- $\alpha$ (GRO$\alpha$ ) and platelet-derived growth factor (PDGF) were also used to measure the concentration of secreted cytokines. The absorbance at $450 \mathrm{~nm}$ was measured with an Immuno Mini NJ-2300 (Nihon InterMed, Tokyo, Japan) and the concentrations were determined using the standard proteins included in the assay kits.

\section{RNA Preparation and Real-Time PCR}

The cultured cells were harvested and directly extracted using TRIzol reagent (Invitrogen), and the total RNA was extracted according to the manufacturer's instructions. The cDNA was synthesized from $1 \mu \mathrm{g}$ of the RNA with the First-Strand Synthesis Kit (Amersham Biosciences) using the oligo dT primer following the manufacturer's protocol. For the real-time PCR reaction (SYBR Green real-time PCR assay; Applied Biosystems, Foster City, Calif., USA), $2 \mu \mathrm{l}$ of the reaction solution was used: $10 \mathrm{~min}$ at $95^{\circ} \mathrm{C}$ followed by 50 cycles consisting of $10 \mathrm{~s}$ at $95^{\circ} \mathrm{C}, 10 \mathrm{~s}$ at $68^{\circ} \mathrm{C}$ and $16 \mathrm{~s}$ at $72^{\circ} \mathrm{C}$, and a final 5 -min extension at $72^{\circ} \mathrm{C}$. IL- 8 and glyceraldehyde 3-phosphate dehydrogenase (GAPDH) PCR kits (Search-LC, Heidelberg, Germany) were used for the quantification of mRNAs and the expression of IL- 8 was normalized to that of GAPDH in the same sample. The fold difference was obtained as the ratio of the normalized value of the samples to the value of untreated control cells.

Mouse Colitis Models and Treatment with Peptides

Male 6-week-old C57/BL6 mice were obtained from Sankyo Labo Service Corporation (Sapporo, Japan) and kept in the animal faculty at Asahikawa Medical College. All mice were housed under conventional conditions with light-dark cycles, fed standard chow and water. To induce colitis, mice were fed 3\% DSS in water for 7 days and the drinking water was changed every few days. The expression of mouse endogenous defensin peptides was compared using AU-PAGE and Coomassie blue staining as previously described $[26,27]$. The additional administration of the peptide was challenged in order to examine its therapeutic appli- cation for mouse colitis. In the first protocol, the adjusted doses of the peptide $(2.5 \mathrm{mg} / \mathrm{kg})$ in $50 \mu \mathrm{l}$ of $0.01 \%$ acetic acid were injected intraperitoneally on days 6,8 and 10 . The survival curves were made with GraphPad Prism (GraphPad Software, Inc., La Jolla, Calif., USA). Some other sets of mice were sacrificed on day 9 for histological analysis and the whole gut was washed with icecold PBS and fixed in 10\% formalin. Thin sections were stained with hematoxylin and eosin. In the second protocol to determine the effect of defensin administration through the gastrointestinal tract, the adjusted doses of the peptide $(2.5 \mathrm{mg} / \mathrm{kg})$ in $50 \mu \mathrm{l}$ of $0.01 \%$ acetic acid were administered using a catheter on day 0 (before-DSS group) or day 8 (after-DSS group). The survival curves were made in the same manner as described above. All mouse experiments were approved by the ethics committee of Asahikawa Medical College.

\section{Statistical Analysis}

The statistical significances of differences and mortality were determined using Student's t test and the log-rank test, respectively. $\mathrm{p}<0.05$ was considered to be significant.

\section{Results}

\section{Characteristics of Recombinant proHD-5}

proHD-5 was successfully expressed in E. coli and purified to a folded form, which is cleaved by trypsin at the N-terminal of Arg (fig. 1a). Since correctly folded proHD-5 is stable against enzymatic cleavage [15], processing by trypsin generated mature HD-5 which was visualized as a fast migrating molecule in AU-PAGE (fig. 1b). The processed peptide migrated as fast as recombinant HD-5 [24]. Purified proHD-5 was demonstrated as a single peak with a slightly shaky start in RP-HPLC (fig.1c) and the purity was still more than $90 \%$. The determined mass value of $8,102.2$ was identical to the calculated mass of $8,102.9$ (fig. 1d).

\section{Comparison of proHD-5 and HD-5 in Their \\ Antibacterial Activities}

Bactericidal activities against 4 different strains were determined (fig. 2). Gram-positive S. aureus strains and Gram-negative E. coli and S. typhimurium were tested as representative bacteria. The $S$. typhimurium phoP-null strain is relatively sensitive to HD-5 and proHD-5 and decreased by less than 3 orders in CFU. Both E. coli strains were also sensitive, but not as sensitive as Salmonella; 2 logs of bacteria were killed by the mature peptide. The same results were seen in 2 different $E$. coli strains. A curious result was that $S$. aureus was eliminated by HD-5 but not by proHD-5. Therefore, species-specific sensitivity to proHD-5 was considered. 

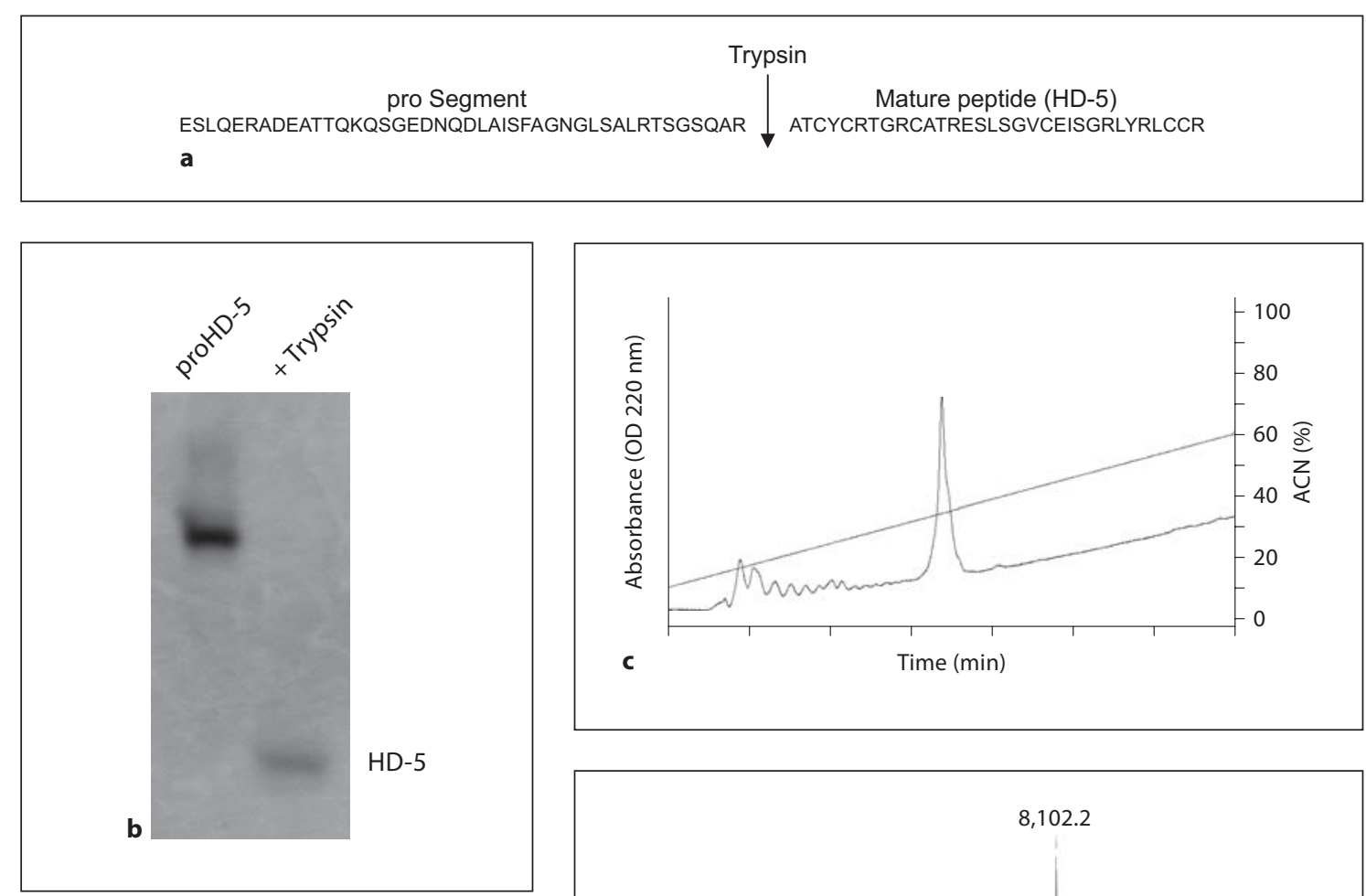

Fig. 1. The recombinant proHD-5 peptide produced with E. coli expression system. a Mature HD-5 cleaved from proHD-5 peptide. The confirmed DNA sequence is used for recombinant synthesis. b Recombinant proHD-5 checked by AU-PAGE showing a single band stained with Coomassie blue staining. Mature HD-5 was observed as a fast migrating band after trypsin treatment. c Purity of proHD-5 peptide checked by RP-HPLC at the gradient of $10-60 \%$ acetonitrile with $0.1 \%$ trifluoroacetic acid. d The observed mass $(8,102.2)$ measured with matrix-assisted laser desorption/ionization time-of-flight mass spectrometry was identical to the calculated mass $(8,102.9)$. $A C N=$ Acetonitrile; $\mathrm{OD}=$ optical density.

\section{IL-8 Released from Colonic Epithelial Cells Is}

Upregulated by HD-5

Colonic cancer cell lines were incubated with the peptides. HD-5 secreted from small intestine is resistant to enzymatic cleavage and transferred to the colon. First, HT-29 was cultured, and released cytokines were examined using the antibody array (fig. 3a). IL-8, GRO and PDGF were constitutively produced by the incubated cells. The secreted cytokines were also measured by ELISA (fig. 3b-d). IL-8 secretion was dramatically induced by the addition of HD-5 and this increase was significantly greater in HT-29 in comparison to SW480 (fig. 4a, b). A dose- and time-dependent increase was seen in the

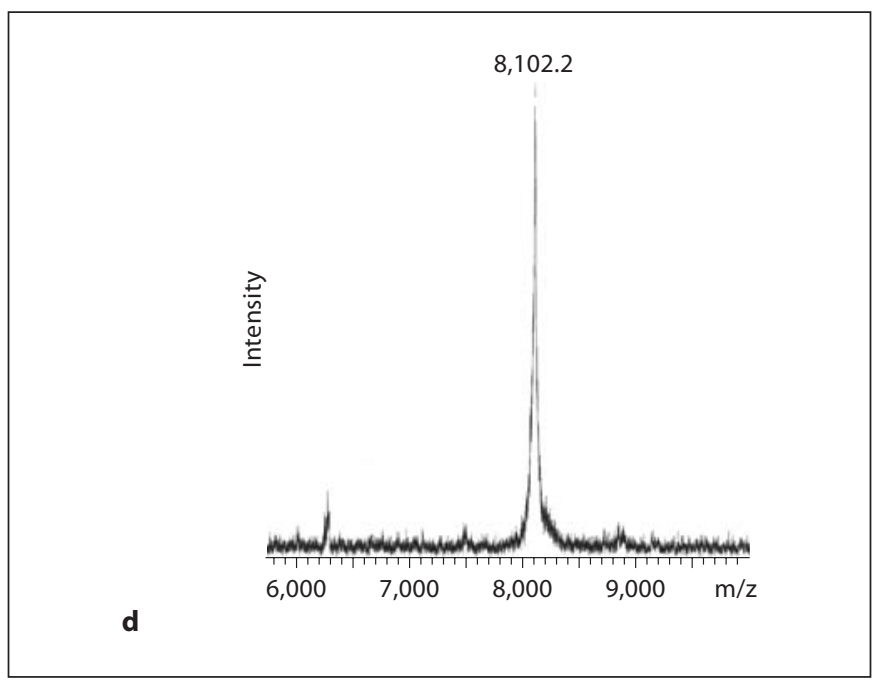

peptide level, and the mRNA expression was induced at $6 \mathrm{~h}$ after incubation and then decreased to the control level at $12 \mathrm{~h}$ (fig. 4c). Little difference was seen in the early phase (data not shown).

\section{Endogenous Mouse Defensin Expression Is}

\section{Constitutive in DSS-Induced Colitis}

Mouse enteric defensin expression was compared in DSS colitis models which were chemically induced and affected mainly the colonic epithelium (fig. 5c). A reduced expression of human enteric defensin is observed in human inflammatory bowel disease [24]. Therefore, the mouse endogenous defensin levels were tested in 
Fig. 2. Antibacterial activity of human defensins (HD). Bacteria at a concentration of $10^{6} \mathrm{CFU} / \mathrm{ml}$ are incubated with HD-5 or proHD-5 in PIPES buffer supplemented with $1 \%$ trypticase soy broth for $1 \mathrm{~h}$. The diluted mixture was plated on trypticase soy broth agar and the grown colonies were counted as bacterial CFU. S. typhimurium, $S$. aureus and E. coli were target organisms as illustrated. Gram-negative $S$. typhimurium phoP-null strain was very sensitive to both peptides. Gram-positive $S$. aureus was eliminated by mature HD-5, but not by proHD-5. Two strains of E. coli showed similar results in the assay.

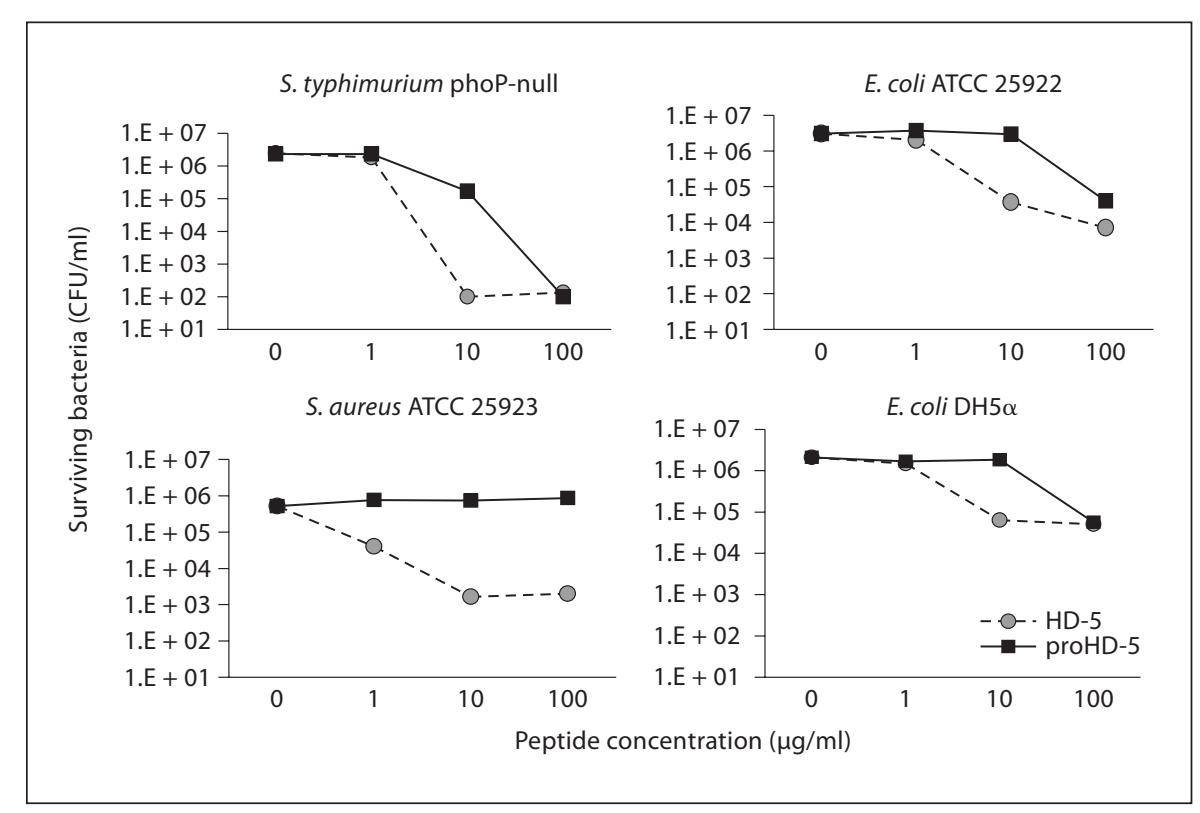

DSS colitis. Mouse defensins, termed cryptdins, were expressed in the Paneth cell granules and the cells are abundant in the terminal ileum (fig. 5a, b). The cryptdins were visualized with AU-PAGE as several bands which migrated fast in the gel. The cryptdins purified from C57BL/6 mice migrated as previously reported [28]. No remarkable difference was detected in the density of the cryptdin peptides (fig. 5d).

\section{Intraperitoneal Administration of HD-5 Improves Prognosis of DSS Colitis}

A chemically induced mouse model was used to determine the effectiveness of the peptides. A dose of $2.5 \mathrm{mg} /$ $\mathrm{kg}$ was estimated based on the in vitro bactericidal concentration. A few injections given to each mouse demonstrated the usefulness of the peptides in vivo. The survival rates of the mice injected with either HD-5 $(n=6)$ or proHD-5 $(n=6)$ were compared with that of the controls $(n=7)$. The survival curve of the mice injected with mature HD-5 was changed significantly $(\mathrm{p}<0.05)$, and survival prolonged compared to that in control mice (fig. 6a). A histological examination showed a marked disruption of epithelia and a severe infiltration of inflammatory cells in the DSS-treated colon, and the severity was reduced by HD- 5 injection (fig. 6b). proHD- 5 showed no improvement in the survival of the DSS colitis mice.
Oral Administration of HD-5 Did Not Alter Prognosis of DSS Colitis

The DSS mice were orally administered HD-5 to identify the most effective routes for this drug medication. The same doses of the peptides were infused into the stomach before and after DSS administration to evaluate the optimal timing of this therapy. Neither HD-5 nor proHD-5 altered the overall survival in the experiments (fig. 7a, b). Regarding these 2 protocols of defensin administration against DSS mice, the route of medication was thus found to play a critical role in achieving innate immunity.

\section{Discussion}

This study investigated whether the activation of $\mathrm{HD}$ is associated with its functions. Mouse defensin activation processing is critical for its bactericidal activity in vivo and in vitro [29]. Mouse defensins are produced as propeptides, cleaved by a processing enzyme and stored in Paneth cell granules. Matrilysin which cleaves the proforms of cryptdins is an activating enzyme of mouse defensins. Matrilysin-deficient mice which lack active mature defensins lose the antibacterial activity released from small intestinal Paneth cells and are therefore sensitive to an oral challenge with a virulent strain of S. typhimurium. Matrilysin-deficient mice are also susceptible to DSS-induced colitis through the blockage of IL-1 $\beta$ re- 


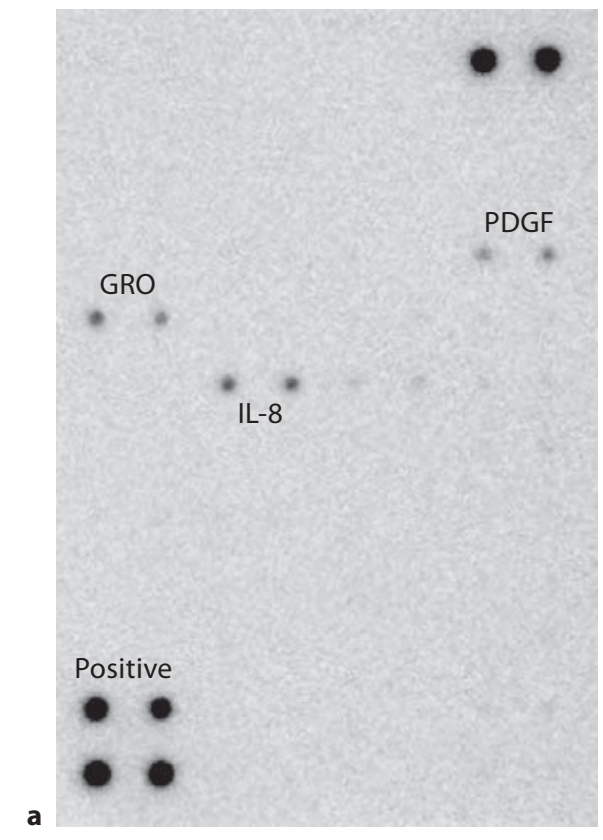

Fig. 3. Secreted cytokines from human colonic epithelial cells. The colonic cancer cell line HT-29 was incubated in DMEM. a After $24 \mathrm{~h}$ incubation, the supernatant was applied using a human cytokine antibody array. The colonic epithelial cells constitutively secreted IL-8, GRO and PDGF. The concentration of IL-8 (b), GRO- $\alpha$ (c) and PDGF (d) was measured using ELISA kits. b IL-8 secretion from HT-29 was increased by HD-5 incubation. c A small increase was shown in the GRO- $\alpha$ concentration. d Little change in PDGF was seen in response to HD-5.

lease from monocytes [30]. Mouse cryptdins may maintain intestinal homeostasis by controlling the production of IL-1 $\beta$ and acting as innate antibacterial molecules.

Strangely enough, HD-5 processing is different from that in the mouse [14]. HD-5 is constitutively produced as a proform, stored in the Paneth cell granules and released in response to bacterial lipopolysaccharide and
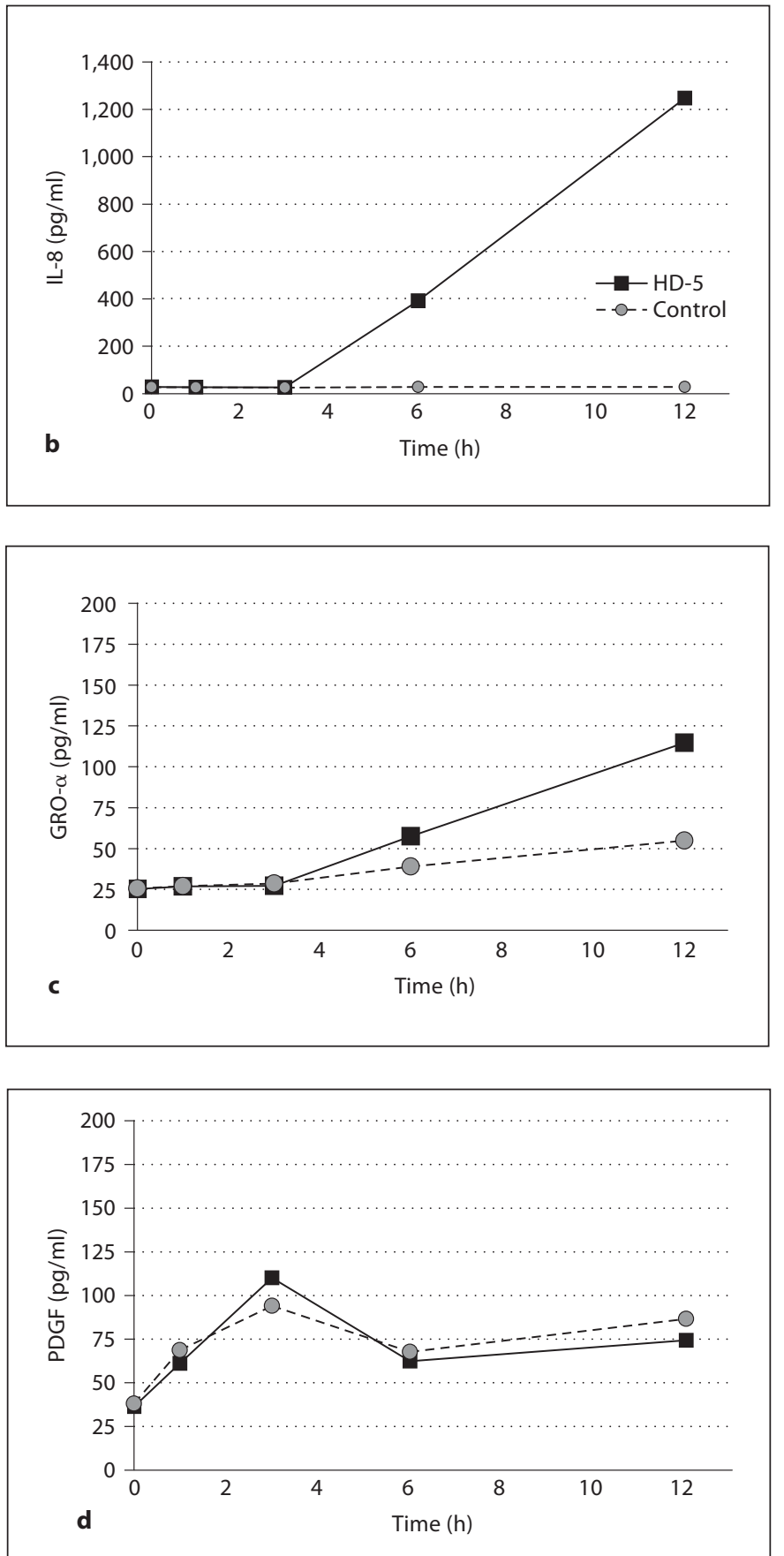

cholinergic reagent [31]. Trypsin which produces mature HD-5 is stored in Paneth cell granules and released from the cells as well [14]. The digestive enzyme cleaves the propeptide to produce the mature form. One of the major cleavage sites is $\mathrm{Arg}^{43}-\mathrm{Ala}^{44}$, and the cleaved peptide is known to be a mature HD-5 peptide. Whether proHD-5 possesses antibacterial activity is still contro- 


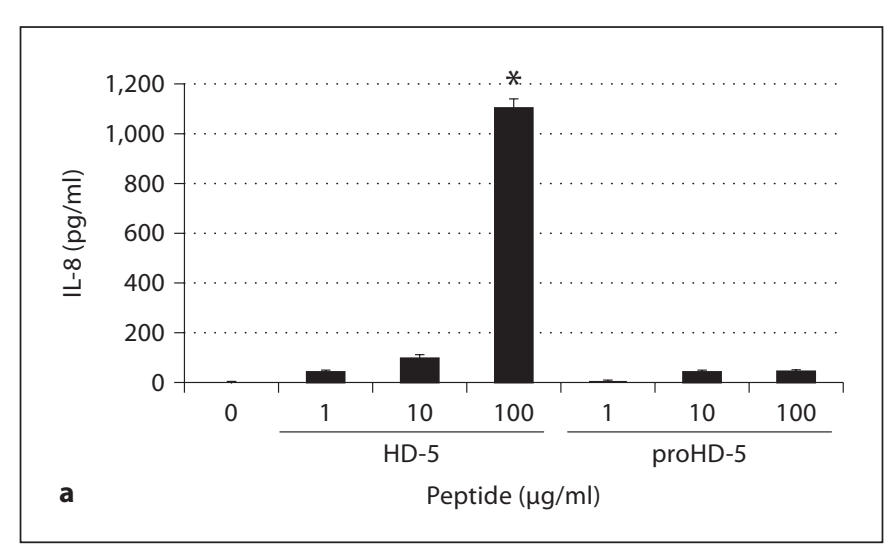

Fig. 4. IL-8 production from colonic epithelial cells. Two colonic cancer cell lines were incubated with different concentrations of HD-5 or proHD-5 for $24 \mathrm{~h}$. The supernatant was assayed using an IL-8 ELISA kit. a HT-29 produced significantly more IL- 8 in response to $100 \mu \mathrm{g} / \mathrm{ml} \mathrm{HD}-5 .{ }^{*} \mathrm{p}<0.0001$ vs. $0 \mu \mathrm{g} / \mathrm{ml}$. b SW480 also secreted IL- 8 in response to HD-5. ${ }^{* *} \mathrm{p}<0.001$ vs. $0 \mu \mathrm{g} / \mathrm{ml}$. c HT29 was harvested after incubation with HD-5 or without HD-5, and RNA was extracted using TRIzol reagent. IL-8 mRNA was measured by real-time PCR, standardized to GAPDH and indicated as arbitrary units. IL- 8 mRNA expression was upregulated $6 \mathrm{~h}$ after culture and returned to the control level at $12 \mathrm{~h}$. The error bars indicate SD. AU = Arbitrary units.

versial. proHD-5 was isolated as an antimicrobial molecule from human normal intestinal tissue using an antibacterial assay [24]. Rose et al. [32] failed to isolate the precursor form with a sensitive antimicrobial assay. Therefore, the role of the activating process in HD has not yet been well characterized. Recombinant proHD-5 was generated to determine its bactericidal activity and immunomodulating ability in comparison with HD-5. HD-5 achieved an antibacterial activity after cleavage by trypsin because HD- 5 was observed to be more active than proHD-5. The mature form of HD-5 was bactericidal for all bacteria at $100 \mu \mathrm{g} / \mathrm{ml}$ in this assay. The physiological HD-5 concentration reported in previous papers is $90-450 \mu \mathrm{g} / \mathrm{ml}$ on the luminal surface or in granules [14]. The concentration used in the current study was almost physiological. Therefore, HD-5 should eliminate enteric bacteria in small intestine. Interestingly, proHD-5 possesses antibacterial activity against some bacterial strains without cleavage. The differences between HD-5 and proHD-5 in their bactericidal activity might depend on the composition of the amino acids. There are 10 positively charged residues (Arg, Lys) in
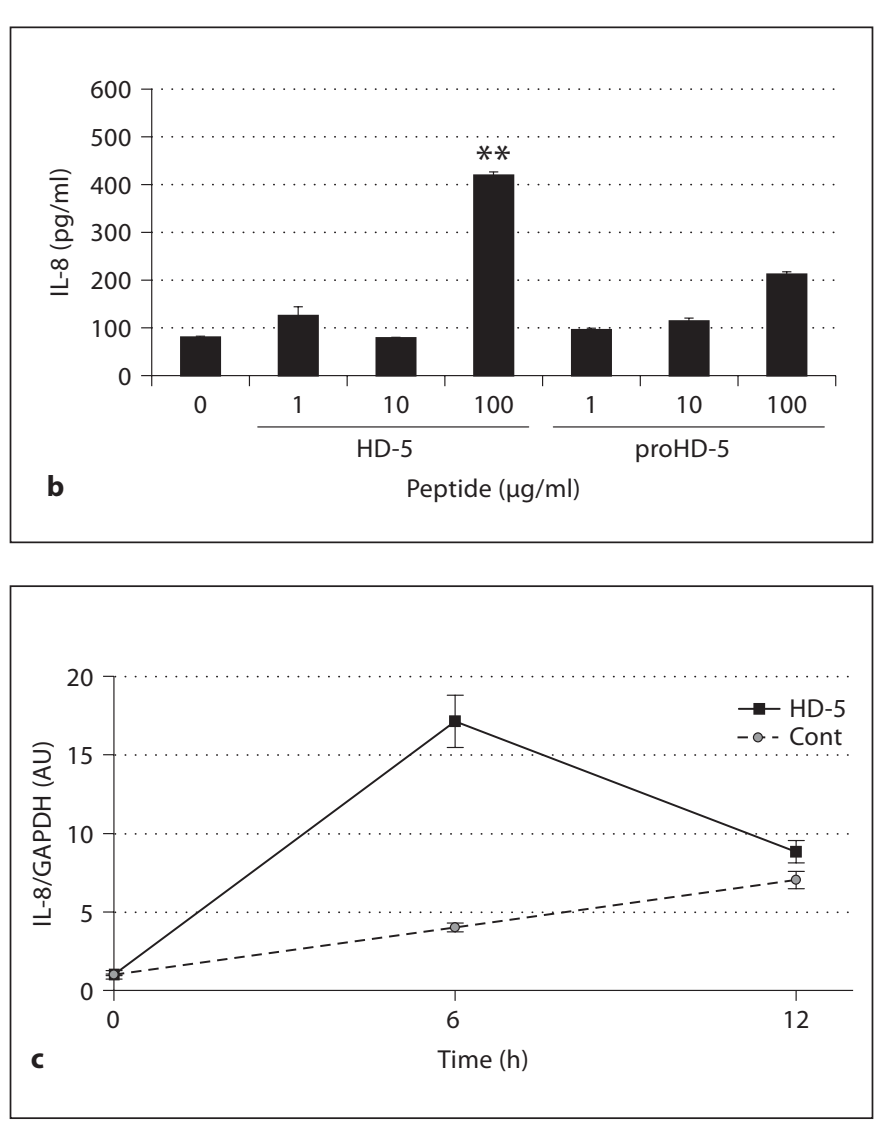

proHD-5, 5 in HD-5, and 9 negatively charged residues (Asp, Glu) in proHD-5 and 2 in HD-5. The net charge of proHD -5 is +1 and that of HD -5 is +3 . The proHD -5 peptide has less net charge than HD-5, but stays cationic. The positive charge is critical for the interaction between the negatively charged bacterial membrane and the antimicrobial peptides [27]. The diversity of sensitivity in different bacterial strains may be caused by the variety of cell wall components.

An additional physiological role of cryptdin was predicted by the observation that cryptdin-3 induces the T84 intestinal epithelial cell line to secrete IL-8 [18]. Cryptdin- 3 acts as a paracrine signaling molecule, cryptdin- 4 does not. HD-5 also induces Caco-2, another colonic cell line to secrete IL-8 [17]. IL- 8 is one of the major cytokines released from colonic epithelial cells and activates neutrophils at the site of inflammation. The production of IL- 8 mRNA and protein was induced by incubation with HD-5. IL-8 or GRO sequentially induces the infiltration of neutrophils and lymphocytes in the intestinal mucosal layer and consequently causes inflammation in the intestinal walls. Mouse and human $\alpha$-defensins block the re- 

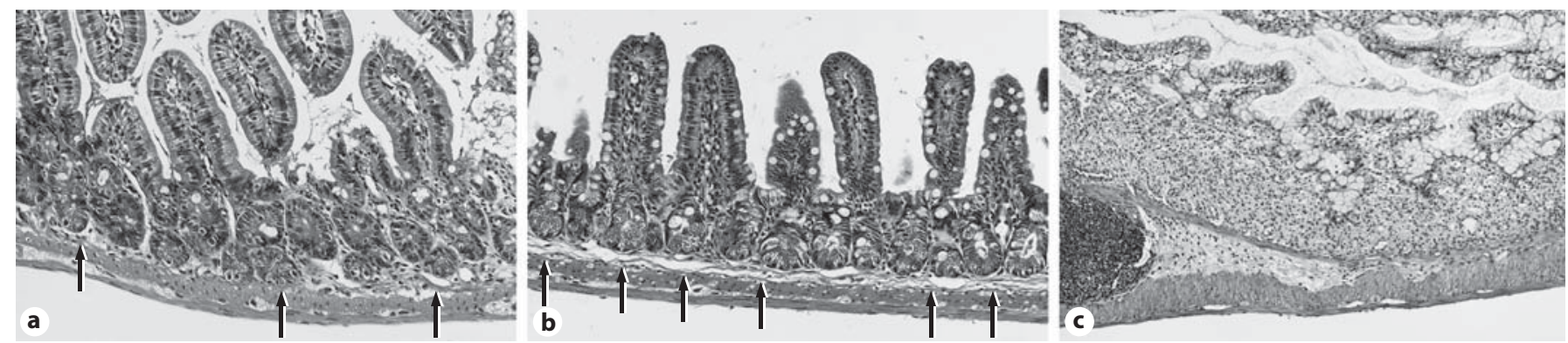

Fig. 5. Reduced intestinal damage in mouse DSS colitis. Histological changes following DSS administration were examined. The proximal intestine (a) and the distal ileum (b) were not affected, and intact Paneth cells were observed at the base of the crypt (arrows). The granule-rich cells were abundant in the terminal ileum. c Distal colonic epithelia were injured, and inflammatory cells had infiltrated the submucosal layer. DSS-induced epithelial damage was mainly found in the colon. $\mathbf{d}$ Endogenous mouse defensins (cryptdins) were examined with AU-PAGE. The mouse small intestine was acid-extracted and $500 \mu \mathrm{g}$ of crude extract were lyophilized. The samples were dissolved in 10 $\mu \mathrm{l}$ of AU-PAGE buffer, separated by electrophoresis on a $12.5 \%$ AU-gel which was stained with Coomassie blue staining. One $\mu \mathrm{g}$ of cryptdin- 4 was loaded as control and migrated faster than the C57BL/6 cryptdins. The fast migrating molecules in the dotted box denote the cryptdins. No remarkable difference was observed in the density of cryptdins. $\mathrm{Cr} 4=$ Cryptdin -4 . a-c $\times 200$.

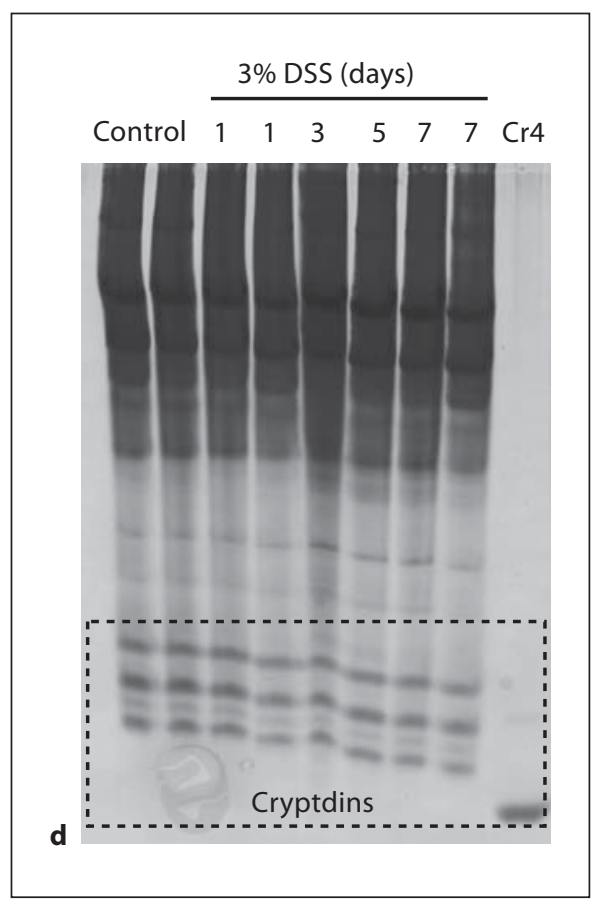

lease of IL-1 $\beta$ from activated monocytes. Moreover, the IL-1 $\beta$ levels are upregulated in matrilysin-deficient mice and, therefore, cryptdin is thought to regulate intestinal homeostasis in vivo [31]. Taken together, defensins regulate the intestinal inflammatory response between epithelial cells and immune cells. The precise network of proinflammatory cytokines, however, still remains to be determined.

The therapeutic ability of human enteric defensin in vivo has been determined. Bevins and colleagues [13] generated an HD-5 transgenic mouse which produces human enteric defensin in Paneth cells as well as mouse endogenous defensin. The mouse is resistant to oral bacterial infections and survives lethal doses of S. typhimurium. Their study indicates that the role of defensin is mainly antibacterial. DSS-induced colitis using this gainof-function model might provide additional information.
Although there are no clinical trials of defensin peptides, the possible clinical application of another antimicrobial peptide was proposed in another previous article [33]. HD-5 has not been tested for the treatment of animal disease models so far. This experiment was the first to demonstrate an improvement of mortality in the colitis model in which mice were treated with lethal doses of the chemicals. The therapeutic effect was not sufficient to save all the mice, but a few exhibited delayed death within a few days. The oral administration of HD-5 did not change mortality in the mice with DSS-induced colitis. The doses of the peptides described in this study may not reach the intestinal lumen or sufficiently alter gut homeostasis. An intraperitoneal injection would not alter the microbial flora which is associated with the cause of mouse colitis. The positive effect of this treatment observed in the present experiment may be due to the mul- 
Fig. 6. Intraperitoneal effect of $\mathrm{HD}$ on mouse DSS colitis. a A lethal concentration of DSS was administrated for 7 days and $5 \mathrm{mg} / \mathrm{kg}$ of the peptide was injected i.p. on days 6, 8 and 10 (HD-5: $n=6$; proHD-5: $\mathrm{n}=6$; vehicle control: $\mathrm{n}=7$ ). The HD-5injected mice survived significantly longer. $\mathrm{p}<0.05$ vs. control. Another separate experiment confirmed this result. b Histological finding of DSS colitis in the distal colon demonstrated disruption of the epithelial layer and severe inflammation in the whole layer. The severity was reduced by HD-5 administration.
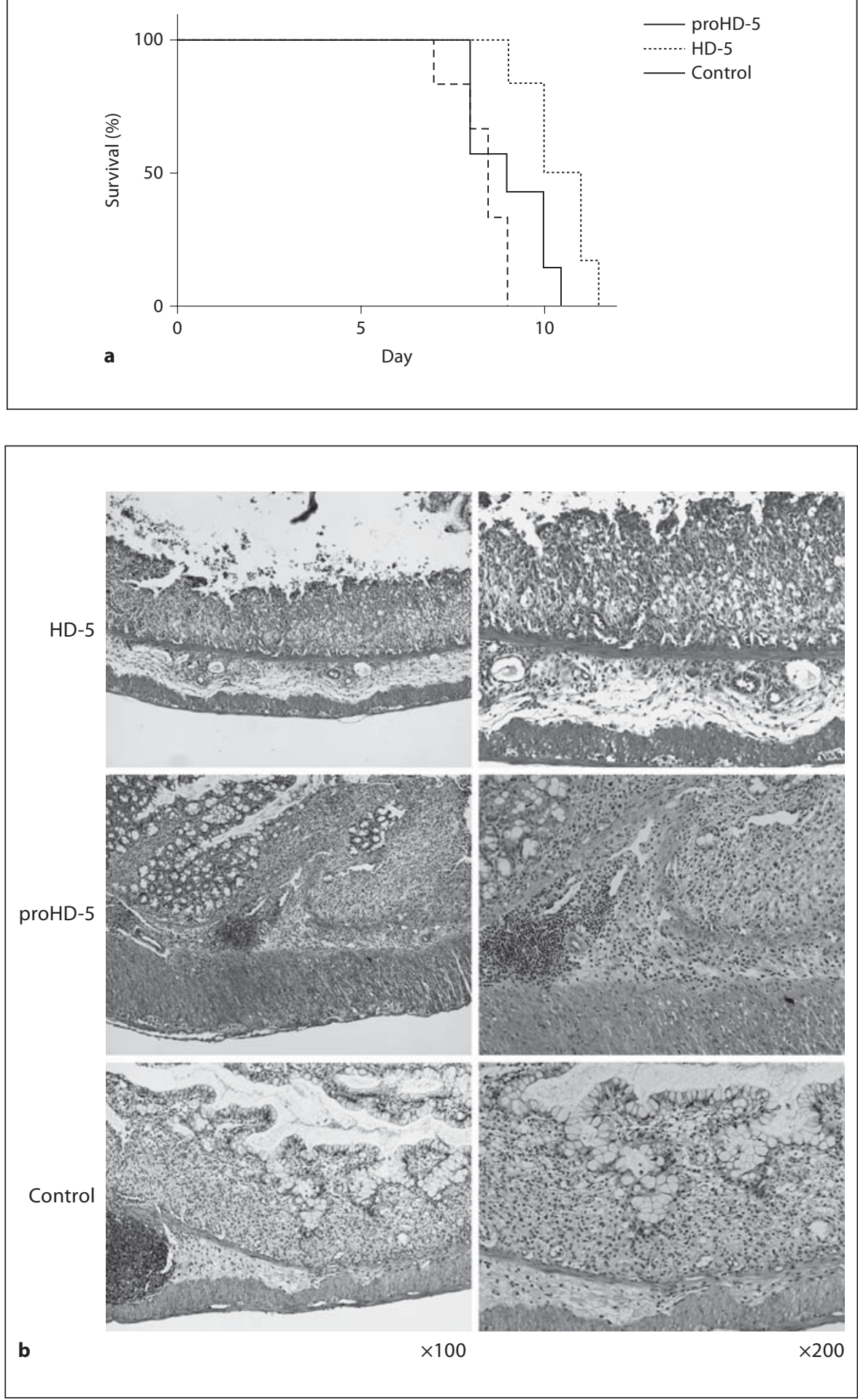

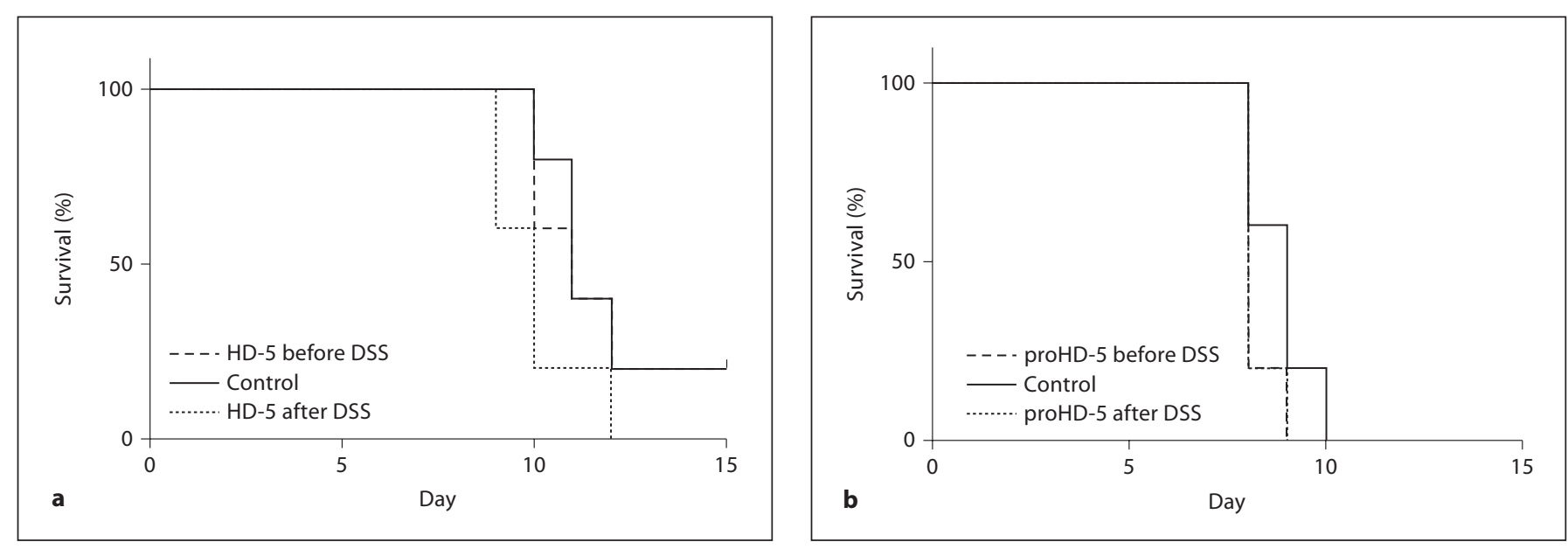

Fig. 7. The effect of orally challenged HD on mouse DSS colitis. a A lethal concentration of DSS was administered for 7 days and $5 \mathrm{mg} / \mathrm{kg}$ of the HD-5 peptide was challenged orally on day 0 (before DSS) or day 8 (after DSS). There were no significant differences among the 3 groups regarding survival. $\mathbf{b}$ proHD-5 was orally challenged for the treatment of mouse DSS colitis in the same manner as that described in the above protocol. No significant differences in survival were observed.

tifunctional effects of antimicrobial peptides. Defensin demonstrates a neutralizing ability in addition to its antimicrobial activity [34]. In this model, bacterial translocation or endotoxemia was the estimated target of the molecule. HD-5 may possess a neutralizing activity for lipopolysaccharide which is one of the components of microbial cell walls. Further experiments are needed to prove our hypothesis and to improve the efficacy of the therapeutic activity.

\section{Acknowledgments}

We thank Akutsu Hiroaki at the Central Laboratory for Research and Education, Asahikawa Medical College, for his excellent technical assistance in performing the mass spectrometry analysis.

This study was supported by a Grant-in-Aid for Scientific Research provided by the Ministry of Education, Culture, Sports, Science and Technology of Japan.

\section{References}

1 Salzman NH, Underwood MA, Bevins CL: Paneth cells, defensins, and the commensal microbiota: a hypothesis on intimate interplay at the intestinal mucosa. Semin Immunol 2007; 19:70-83.

$\checkmark 2$ Ayabe T, Ashida T, Kohgo Y, Kono T: The role of Paneth cells and their antimicrobial peptides in innate host defense. Trends Microbiol 2004; 12:394-398.

$\checkmark 3$ Selsted ME, Miller SI, Henschen AH, Ouellette AJ: Enteric defensins: antibiotic peptide components of intestinal host defense. J Cell Biol 1992;118:929-936.

4 Porter EM, Bevins CL, Ghosh D, Ganz T: The multifaceted Paneth cell. Cell Mol Life Sci 2002;59:156-170.
Ayabe T, Satchell DP, Wilson CL, Parks WC, Selsted ME, Ouellette AJ: Secretion of microbicidal alpha-defensins by intestinal Paneth cells in response to bacteria. Nat Immunol 2000;1:113-118.

6 Wehkamp J, Chu H, Shen B, Feathers RW, Kays RJ, Lee SK, Bevins CL: Paneth cell antimicrobial peptides: topographical distribution and quantification in human gastrointestinal tissues. FEBS Lett 2006;580: 5344-5350.

7 Meyer-Hoffert U, Hornef MW, HenriquesNormark B, Axelsson LG, Midtvedt T, Putsep K, Andersson M: Secreted enteric antimicrobial activity localises to the mucus surface layer. Gut 2008;57:764-771.

$\checkmark 8$ Hooper LV, Stappenbeck TS, Hong CV, Gordon JI: Angiogenins: a new class of microbicidal proteins involved in innate immunity. Nat Immunol 2003;4:269-273.
Ouellette AJ, Hsieh MM, Nosek MT, CanoGauci DF, Huttner KM, Buick RN, Selsted ME: Mouse Paneth cell defensins: primary structures and antibacterial activities of numerous cryptdin isoforms. Infect Immun 1994;62:5040-5047.

10 Karlsson J, Putsep K, Chu H, Kays RJ, Bevins $\mathrm{CL}$, Andersson M: Regional variations in $\mathrm{Pa}$ neth cell antimicrobial peptide expression along the mouse intestinal tract. BMC Immunol 2008;9:37.

11 Mallow EB, Harris A, Salzman N, Russell JP, DeBerardinis RJ, Ruchelli E, Bevins CL: Human enteric defensins. Gene structure and developmental expression. J Biol Chem 1996; 271:4038-4045. 
12 George MD, Wehkamp J, Kays RJ, Leutenegger CM, Sabir S, Grishina I, Dandekar S, Bevins CL: In vivo gene expression profiling of human intestinal epithelial cells: analysis by laser microdissection of formalin fixed tissues. BMC Genomics 2008;9:209.

$\checkmark 13$ Salzman NH, Ghosh D, Huttner KM, Paterson Y, Bevins CL: Protection against enteric salmonellosis in transgenic mice expressing a human intestinal defensin. Nature 2003; 422:522-526.

- 14 Ghosh D, Porter E, Shen B, Lee SK, Wilk D, Drazba J, Yadav SP, Crabb JW, Ganz T, Bevins CL: Paneth cell trypsin is the processing enzyme for human defensin-5. Nat Immunol 2002;3:583-590.

15 Rajabi M, de Leeuw E, Pazgier M, Li J, Lubkowski J, Lu W: The conserved salt bridge in human alpha-defensin 5 is required for its precursor processing and proteolytic stability. J Biol Chem 2008;283:21509-21518.

- 16 van Wetering S, Mannesse-Lazeroms SP, Dijkman JH, Hiemstra PS: Effect of neutrophil serine proteinases and defensins on lung epithelial cells: modulation of cytotoxicity and IL-8 production. J Leukoc Biol 1997;62: 217-226.

-17 de Leeuw E, Burks SR, Li X, Kao JP, Lu W: Structure-dependent functional properties of human defensin 5. FEBS Lett 2007;581: 515-520.

- 18 Lin PW, Simon PO Jr, Gewirtz AT, Neish AS, Ouellette AJ, Madara JL, Lencer WI: Paneth cell cryptdins act in vitro as apical paracrine regulators of the innate inflammatory response. J Biol Chem 2004;279:19902-19907.

-19 Wehkamp J, Harder J, Weichenthal M, Schwab M, Schäffeler E, Schlee M, Herrlinger KR, Stallmach A, Noack F, Fritz P, Schröder JM, Bevins CL, Fellermann K, Stange EF: NOD2 (CARD15) mutations in Crohn's disease are associated with diminished mucosal alpha-defensin expression. Gut 2004;53:1658-1664.
20 Wehkamp J, Salzman NH, Porter E, Nuding S, Weichenthal M, Petras RE, Shen B, Schaeffeler E, Schwab M, Linzmeier R, Feathers RW, Chu H, Lima H Jr, Fellermann K, Ganz T, Stange EF, Bevins CL: Reduced Paneth cell alpha-defensins in ileal Crohn's disease. Proc Natl Acad Sci USA 2005; 102:1812918134.

21 Kobayashi KS, Chamaillard M, Ogura Y, Henegariu O, Inohara N, Nuñez G, Flavell RA: Nod2-dependent regulation of innate and adaptive immunity in the intestinal tract. Science 2005;307:731-734.

22 Wehkamp J, Wang G, Kubler I, Nuding S, Gregorieff A, Schnabel A, Kays RJ, Fellermann K, Burk O, Schwab M, Clevers H, Bevins CL, Stange EF: The Paneth cell alphadefensin deficiency of ileal Crohn's disease is linked to Wnt/Tcf-4. J Immunol 2007;179: 3109-3118.

23 Koslowski MJ, Kubler I, Chamaillard M, Schaeffeler E, Reinisch W, Wang G, Beisner J, Teml A, Peyrin-Biroulet L, Winter S, Herrlinger KR, Rutgeerts P, Vermeire S, Cooney $\mathrm{R}$, Fellermann K, Jewell D, Bevins CL, Schwab M, Stange EF, Wehkamp J: Genetic variants of Wnt transcription factor TCF-4 (TCF7L2) putative promoter region are associated with small intestinal Crohn's disease. PLoS One 2009;4:e4496.

-24 Tanabe H, Ayabe T, Maemoto A, Ishikawa C, Inaba Y, Sato R, Moriichi K, Okamoto K, Watari J, Kono T, Ashida T, Kohgo Y: Denatured human alpha-defensin attenuates the bactericidal activity and the stability against enzymatic digestion. Biochem Biophys Res Commun 2007;358:349-355.

25 Tanabe H, Sato T, Watari J, Maemoto A, Fijiya M, Kono T, Ashida T, Ayabe T, Kohgo Y: Functional role of metaplastic Paneth cell defensins in Helicobacter pylori-infected stomach. Helicobacter 2008; 13:370-379.

26 Ouellette AJ, Darmoul D, Tran D, Huttner KM, Yuan J, Selsted ME: Peptide localization and gene structure of cryptdin 4 , a differentially expressed mouse paneth cell alpha-defensin. Infect Immun 1999;67:6643-6651.
27 Tanabe H, Qu X, Weeks CS, Cummings JE, Kolusheva S, Walsh KB, Jelinek R, Vanderlick TK, Selsted ME, Ouellette AJ: Structureactivity determinants in Paneth cell alpha-defensins: loss-of-function in mouse cryptdin- 4 by charge-reversal at arginine residue positions. J Biol Chem 2004;279:11976-11983.

28 Shirafuji Y, Tanabe H, Satchell DP, Henschen-Edman A, Wilson CL, Ouellette AJ: Structural determinants of procryptdin recognition and cleavage by matrix metalloproteinase-7. J Biol Chem 2003;278:7910-7919.

$\checkmark 29$ Wilson CL, Ouellette AJ, Satchell DP, Ayabe T, Lopez-Boado YS, Stratman JL, Hultgren SJ, Matrisian LM, Parks WC: Regulation of intestinal alpha-defensin activation by the metalloproteinase matrilysin in innate host defense. Science 1999;286:113-117.

- 30 Shi J, Aono S, Lu W, Ouellette AJ, Hu X, Ji Y, Wang L, Lenz S, van Ginkel FW, Liles M, Dykstra C, Morrison EE, Elson CO: A novel role for defensins in intestinal homeostasis: regulation of IL-1beta secretion. J Immunol 2007;179:1245-1253.

-31 Cunliffe RN, Mahida YR: Antimicrobial peptides in innate intestinal host defence. Gut 2000;47:16-17.

32 Rose FR, Bailey K, Keyte JW, Chan WC, Greenwood D, Mahida YR: Potential role of epithelial cell-derived histone $\mathrm{H} 1$ proteins in innate antimicrobial defense in the human gastrointestinal tract. Infect Immun 1998; 66:3255-3263

33 Mygind PH, Fischer RL, Schnorr KM, Hansen MT, Sonksen CP, Ludvigsen S, Raventos D, Buskov S, Christensen B, de Maria L, Taboureau O, Yaver D, Elvig-Jorgensen SG, Sorensen MV, Christensen BE, Kjaerulff S, Frimodt-Moller N, Lehrer RI, Zasloff M, Kristensen HH: Plectasin is a peptide antibiotic with therapeutic potential from a saprophytic fungus. Nature 2005;437:975-980.

34 Motzkus D, Schulz-Maronde S, Heitland A, Schulz A, Forssmann WG, Jubner M, Maronde E: The novel beta-defensin DEFB123 prevents lipopolysaccharide-mediated effects in vitro and in vivo. FASEB J 2006;20: 1701-1702. 